\title{
Pupuk Organik dari Limbah Pabrik Gula Madukismo dengan Starter Mikrobia Pengurai Untuk Menambah Kandungan N, P, K
}

\author{
Ratna Sri Harjanti \\ Program Studi Teknik Kimia Politeknik LPP, Jl. LPP No. 1A, Balapan Yogyakarta \\ E-mail: ratna_sh@politeknik-lpp.ac.id
}

\begin{abstract}
Filter cake (blotong) is a dark-colored sludge resulting from sugar mill waste, it often dumped, causing pollution and odor. Filter cake is produced from about 3.8\% of sugar cane that is milled by a sugar factory. Vinasse is waste water generated from alcohol making process. In the process of making one liter of alcohol, it will produce 13 liters of vinasse. Vinasse contains many K elements while filter cake contains a lot of N, $P$ and Ca elements. This allows for composting filter cake with the addition of vinasse to produce organic fertilizer. Filter cake and vinasse can be found in Madukismo sugar factory (PG Madukismo). Organic fertilizer through composing the mixture of filter cake and vinasse using microbial starter EM-4 and XCompost can be done easily at home environment. In order to determine the optimum process conditions to produce organic fertilizer, the ratio of filter cake and vinasse composition need to be varied. Composting reaction experiment was carried out for thirty days with observation in its temperature and $\mathrm{pH}$. Next, analysis on $N, P, K$, and $C / N$ ratio was conducted. Based on the results obtained, the use of starter microbes $X$-compost is more prospective than using starter microbes EM-4. The compost produced by the starter microbes X-compost contains higher $N, P, K$ than the compost produced by the starter microbes EM-4. Adding more vinasse will give optimum results if the addition of vinasse is $25 \%$ of the weight of filter cake.
\end{abstract}

Keywords: filter cake, vinasse, compost, microbe

\section{Pendahuluan}

Perkembangan industri yang semakin pesat, membawa dampak positif ataupun dampak negative. Dampak positifnya adalah dapat mengurangi angka pengangguran dan meningkatkan kesejahteraan rakyat. Sedangkan dampak negatifnya adalah semakin banyaknya limbah industri yang dihasilkan. Permasalahannya sekarang adalah tidak hanya mencari solusi bagaimana limbah tersebut dapat bersahabat dengan manusia dan lingkungannya, namun akan lebih penting lagi bagaimana limbah tersebut dapat diolah menjadi bahan yang lebih bermanfaat. Sebagai contoh adalah ndustri gula nasional yang saat ini sedang berkembang pesat. Hal ini menyebabkan semakin menumpuknya blotong yang merupakan limbah pabrik gula.

Pabrik Gula Madukismo dan Pabrik Spritus Madukismo adalah salah satu pabrik gula di Indonesia yang menghasilkan blotong dan vinasse dalam jumlah besar setiap tahunnya. Blotong adalah limbah pabrik gula yang berbentuk lumpur berwarna gelap, yang sering dibuang sehingga menimbulkan polusi bau. Blotong diproduksi sekitar 3,8\% tebu yang digiling oleh suatu unit pabrik gula [1]. Sedangkan vinasse merupakan limbah cair yang dihasilkan dari proses pembuatan alkohol atau spritus. Dalam proses pembuatan 1 Liter alcohol akan dihasilkan vinasse sebanyak 13 liter. Dari angka perbandingan di atas, semain banyak alcohol yang diproduksi akan semakin banyak pula vinasse yang dihasilkan [2].

Secara umum, bentuk blotong berupa serpihan serat-serat tebu yang mempunyai komposisi humus, Ntotal, $\mathrm{C} / \mathrm{N}, \mathrm{KIO}, \mathrm{CaO}$ dan $\mathrm{MgO}$, yang cukup baik untuk dijadikan bahan pupuk organik. Blotong dapat memperbaiki fisik tanah, khususnya meningkatkan kapasitas menahan air, menurunkan laju pencucian hara dan memperbaiki drainase tanah. Manfaat blotong sebagai pupuk tanaman tebu dapat meningkatkan bobot dan rendemen tebu secara signifikan untuk setiap 100 ton blotong per hektar tanaman tebu [1]. Pabrik Gula Madukismo sendiri telah berusaha mengatasi limbah blotong tersebut untuk diolah menjadi pupuk organik berbentuk granula dan diberi nama "madros". Berdasarkan pengamatan di lapangan, ternyata efektivitas pupuk tersebut masih rendah. Hal ini kemungkinan disebabkan karena dua faktor, yaitu proses pengomposan sebelum proses pengubahan bentuk menjadi granula belum optimal dan tidak adanya unsur yang ditambahkan ke dalam blotong yang bisa memperkaya kandungan hara yang dihasilkan.

Vinasse kaya akan unsur K, terdiri dari campuran komponen organik dan anorganik. Komposisi campuran tergantung dari bahan baku yang digunakan dalam proses fermentasi alkohol. Vinasse berwarna coklat terang dengan kandungan padatan berkisar 20.000-40.000 $\mathrm{mg} / \mathrm{L}$, bersuhu $65-105{ }^{\circ} \mathrm{C}$. Vinasse adalah cairan yang 
bersifat asam dengan pH antara 4-5 dan mempunyai nilai Chemical Oxygen Demand (COD) yang tinggi. Padatan anorganiknya mengandung sejumlah nutrient seperti phosphor, nitrogen, dan potassium [2].

Berdasarkan pernyataan di atas bahwa adanya kemungkinan pembuatan pupuk organik yang berasal dari blotong dan vinasse. Vinasse kaya akan unsur K, sedangkan blotong kaya akan unsur N, P, dan Ca, sehingga diharapkan pupuk organik yang dihasilkan akan mempunyai kandungan hara yang lebih lengkap dibandingkan dengan pupuk blotong yang sudah pernah dibuat. Sedangkan untuk mengoptimalkan proses pengomposan blotong, dapat digunakan starter mikrobia pengurai, seperti EM-4, X-kompos, Stardec dan sebagainya yang banyak dijual di pasaran.

Pupuk organik adalah pupuk yang sebagian besar atau seluruhnya terdiri dari bahan organik yang berasal dari tanaman dan atau hewan yang telah melalui proses rekayasa, dapat berbentuk padat atau cair yang digunakan untuk mensuplai bahan organik, memperbaiki sifat fisik, kimia, dan biologi tanah [3]. Manfaat pupuk organik adalah untuk meningkatkan bahan organik tanah yang merupakan salah satu komponen tanah yang sangat penting bagi ekosistem tanah, dimana bahan organik merupakan sumber pengikat hara dan substrat bagi mikrobia tanah. Bahan organik secara fisik mendorong granulasi, mengurangi plastisitas dan meningkatkan daya pegang air [3].

Penggunaan pupuk organik akan meningkatkan efisiensi penyerapan hara oleh tanaman. Penggunaan pupuk organik yang dikombinasikan dengan pupuk kimia dapat mengurangi dosis pupuk kimia, serapan hara tanaman meningkat dan produksinya pun cenderung menjadi lebih tinggi [4]. Salah satu rekayasa pembuatan pupuk organik adalah pengomposan. Pengomposan merupakan suatu metode untuk mengkonversikan bahanbahan organik menjadi bahan yang lebih sederhana dengan menggunakan aktivitas mikroba [3]. Pengomposan dapat dilakukan pada kondisi aerobik dan anaerobik. Pengomposan aerobik memerlukan udara dan menghasilkan karbondioksida, air dan panas. Pengomposan anaerobik tidak memerlukan oksigen dan menghasilkan metana, karbondioksida, dan senyawa intermediate seperti asam-asam organik dengan berat molekul rendah [3].

Starter mikroba pengurai banyak digunakan untuk proses pembuatan kompos atau pupuk organik berbahan baku sampah atau limbah padat maupun cair. Beberapa contoh starter mikrobia pengurai antara lain: X-kompos, EM-4, Primadec, Stardec, dan sebagainya. Setiap starter mempunyai karakteristik dan jenis mikrobia yang berbeda-beda. EM-4 merupakan mikroorganisme yang dapat meningkatkan mikrobia tanah, memperbaiki kesehetan dan kualitas tanah serta mempercepat pengomposan. Mikroorganisme ini memberikan pengaruh yang baik terhadap kualitas kompos. Sedangkan ketersediaan unsur hara dalam kompos sangat dipengaruhi oleh lamanya waktu yang diperlukan oleh bakteri untuk mendegradasi bahan organik [5]. X-kompos merupakan kumpulan mikroorganisme (mikroba probiolitik, selulolitik, lignolitik, lipolitik, dan aminolitik serta nitrogen fiksasi non simbiosis) yang mampu menguraikan bahan organik kompleks menjadi bahan organik yang lebih sederhana [6]. Di dalam penelitian ini menggunakan kedua starter tersebut untuk menentukan starter manakah yang memberikan komposisi kompos paling optimal.

\section{Metode Penelitian}

Alat-alat yang digunakan dalam penelitian ini, yaitu:

1. drum dan tutupnya

2. alat pelubang drum

3. sarung tangan

4. masker

5. pengaduk adonan kompos

6. thermometer tanah

Bahan-bahan yang digunakan dalam penelitian ini, yaitu:

1. blotong

2. vinasse

3. starter mikrobia EM-4

4. starter mikrobia Starbio 
Pelaksanaan penelitian:

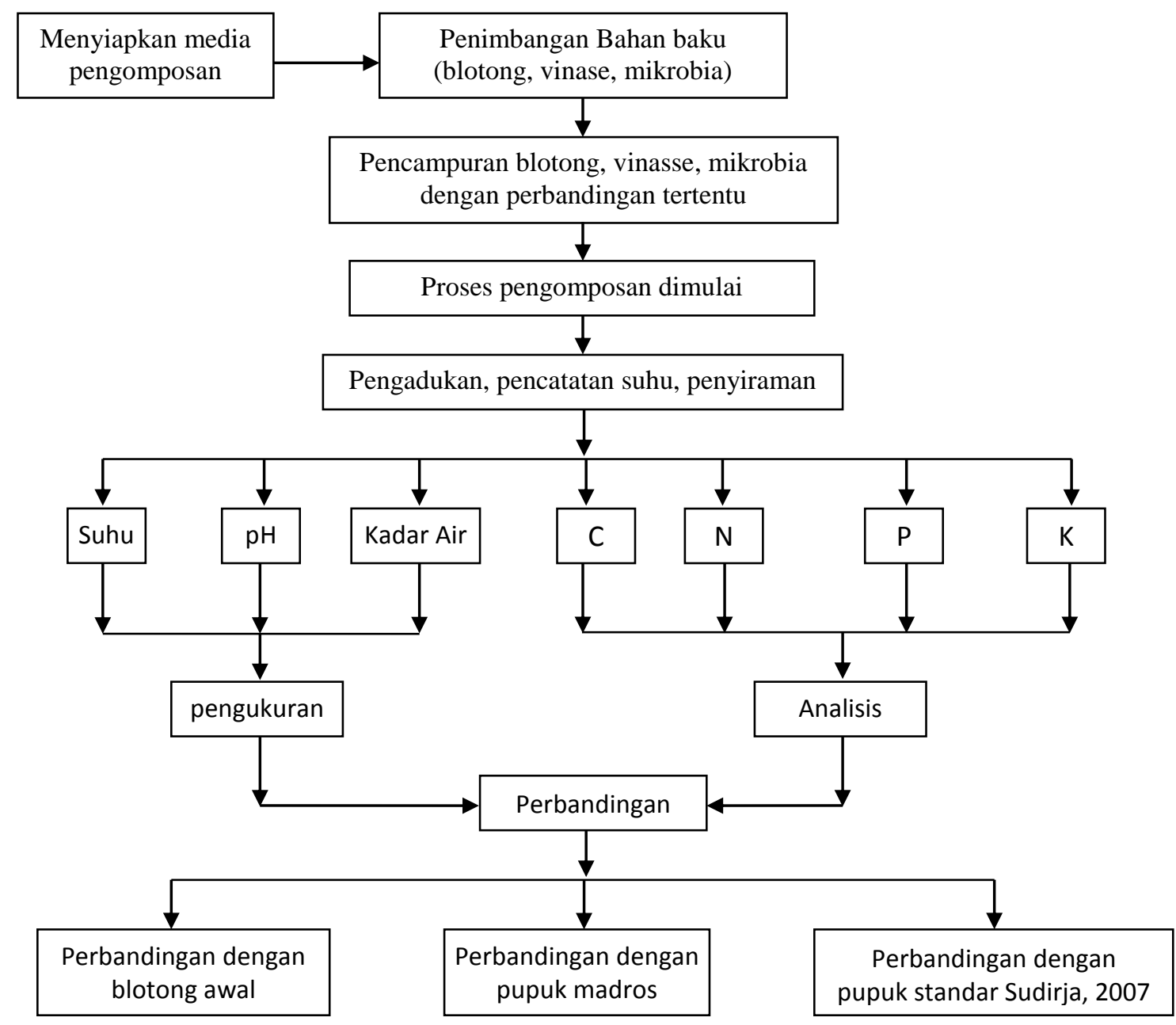

Gambar 1. Diagram Alir Penelitian

Analisis yang dilakukan dalam penelitian ini, yaitu; untuk mengetahui kandungan pupuk antara lain: analisis kandungan $\mathrm{C}, \mathrm{N}$, $\mathrm{P}$ dalam senyawa $\mathrm{P}_{2} \mathrm{O}_{5}$ dan $\mathrm{K}$ dalam senyawa $\mathrm{K}_{2} \mathrm{O}$. Dalam penelitian ini, analisis tersebut dilakukan di Balai Pengkajian Teknologi Pertanian Yogyakarta dengan metode labu kjedahl dan spektrometri.

\section{Hasil Penelitian dan Pembahasan}

Kandungan blotong pada awal pengomposan

Blotong yang berasal dari PG Madukismo memiliki rasio $\mathrm{C} / \mathrm{N}$ yang rendah. Mikrobia perombak bahan organik memerlukan karbon dan nitrogen dari bahan asalnya. Karbon dibutuhkan untuk sumber energi pertumbuhannya dan nitrogen diperlukan untuk membentuk protein. Rasio $\mathrm{C} / \mathrm{N}$ yang efektif untuk proses pengomposan berkisar antara 30:1 hingga 40:1. Mikroba memecah senyawa $\mathrm{C}$ sebagai sumber energy dan menggunakan $\mathrm{N}$ untuk sintesis protein. Pada rasio $\mathrm{C} / \mathrm{N}$ diantara $30 \mathrm{~s} / \mathrm{d} 40$ mikroba mendapatkan cukup untuk energy dan $\mathrm{N}$ untuk sintesis protein. Apabila rasio $\mathrm{C} / \mathrm{N}$ terlalu tinggi, mikroba kekurangan $\mathrm{N}$ untuk sintesis protein, sehingga dekomposisi berjalan lambat [7].

Karena pada awal pengomposan rasio $\mathrm{C} / \mathrm{N}$ blotong yang akan dikomposkan sudah sangat rendah sekitar 6,88. Sehingga penambahan vinasse dan starter mikrobia pada proses pengomposan blotong ini ditujukan untuk menambah unsur hara $\mathrm{N}, \mathrm{P}$, dan $\mathrm{K}$ pada pupuk organik yang akan dihasilkan. 
Tabel 1. Hasil Analisis Blotong pada Awal Pengomposan

\begin{tabular}{cccccc}
\hline \multirow{2}{*}{ No } & \multirow{2}{*}{ Jenis Analisis } & \multicolumn{3}{c}{ Hasil Analisis (\%) } & \multirow{2}{*}{ Rerata (\%) } \\
\cline { 3 - 5 } & & Sampel I & Sampel II & Sampel III & \\
\hline 1 & Nitrogen (N) & 1,04 & 1,14 & 1,02 & 1,07 \\
2 & Fosfat $\left(\mathrm{P}_{2} \mathrm{O}_{5}\right)$ & 1,325 & 0,975 & 1,175 & 1 \\
3 & Karbon ( C ) & 12,38 & 12,14 & 12,53 & 12,35 \\
4 & Rasio C/N & 6,86 & 6,88 & 6,89 & 6,88 \\
5 & $\mathrm{pH}$ & 6,6 & 6,6 & 6,6 & 6,6 \\
6 & Kalium $\left(\mathrm{K}_{2} \mathrm{O}\right)$ & 0,6825 & 0,6825 & 0,6825 & 0,6825 \\
\hline
\end{tabular}

Pengomposan

Proses pengomposan akan segera berlangsung setelah bahan-bahan mentah dicampur. Proses pengomposan secara sederhana dapat dibagi menjadi dua tahap, yaitu tahap aktif dan tahap pematangan. Selama tahap-tahap awal proses, oksigen dan senyawa-senyawa yang mudah terdegradasi akan segera dimanfaatkan oleh mikroba mesofilik. Suhu tumpukan kompos akan meningkat dengan cepat.

Peningkatan suhu merupakan indikator adanya proses dekomposisi sebagai akibat hubungan kadar air dan kerja mikroorganisme. Pada saat bahan organik dirombak oleh mikroorganisme maka dibebaskanlah sejumlah energi berupa panas. Pada tahap awal pengomposan mikroorganisme memperbanyak diri secara cepat dan menaikkan suhu [8].

Pada pengomposan aerobik, diawal suhu meningkat pesat mulai dari $30^{\circ} \mathrm{C}$ hingga mencapai $60{ }^{\circ} \mathrm{C}$, dan suhu akan tetap tinggi selama waktu tertentu. Mikroba yang aktif pada kondisi ini adalah mikroba Termofilik, yaitu mikroba yang aktif pada suhu tinggi. Pada saat ini terjadi dekmposisi/penguraian bahan organik yang sangat aktif. Mikroba-mikroba di dalam kompos dengan menggunakan oksigen akan menguraikan bahan organik menjadi $\mathrm{CO}_{2}$, uap air dan panas. Organisme yang bertugas dalam menghancurkan material organik membutuhkan nitrogen $(\mathrm{N})$ dalam jumlah yang besar. Oleh karena itu, dalam proses pengomposan perlu ditambahkan material yang mengandung nitrogen agar berlangsung proses pengomposan secara sempurna. Dalam penelitian ini ditambahkan vinasse yang mengandung nitrogen. Nitrogen akan bersatu dengan mikroba selama proses penghancuran material organik. Setelah proses pembusukan selesai, nitrogen akan dilepaskan kembali sebagai salah satu komponen yang terkandung dalam kompos.

Berikut ini adalah hasil pengukuran suhu pada proses pengomposan yang telah dilakukan. Pengomposan terjadi selama tiga puluh hari, setiap harinya suhu selalu diukur dan dilakukan pengadukan bahan serta penyiraman dengan air. Seminggu sekali dilakukan analisis rasio $\mathrm{C} / \mathrm{N}$ untuk mengetahui kematangan kompos. Kompos akan matang apabila rasio $\mathrm{C} / \mathrm{N}$ sudah relatif stabil dan kompos memberikan aroma yang harum, tidak menimbulkan bau yang tidak sedap lagi.

Setelah sebagian besar bahan telah terurai, maka suhu akan berangsur-angsur mengalami penurunan. Pada saat ini terjadi pematangan kompos tingkat lanjut, yaitu pembentukan komplek liat humus. Selama proses pengomposan akan terjadi penyusutan volume maupun biomassa bahan. Pengurangan ini dapat mencapai 30$40 \%$ dari volume/bobot awal bahan [3].

Analisis kadar N pada Akhir Pengompsan

Berikut ini adalah hasil analisis kadar $\mathrm{N}$ blotong pada akhir pengomposan dan grafik hubungan prosentase penambahan vinasse dengan starter mikrobia yang digunakan.

Tabel 2. Hasil Analisis Kadar N Pada Akhir Pengomposan

\begin{tabular}{cccc}
\hline \multirow{2}{*}{ No. } & \multirow{2}{*}{ Prosentase Vinase } & \multicolumn{2}{c}{ Kadar N (\%) } \\
\cline { 3 - 4 } & & EM- 4 & X Kompos \\
\hline 1 & $0 \%$ & 1,41 & 2,88 \\
2 & $10 \%$ & 2,66 & 2,71 \\
3 & $15 \%$ & 2,01 & 3,02 \\
4 & $20 \%$ & 1,92 & 2,02 \\
5 & $25 \%$ & 2,17 & 4,16 \\
\hline
\end{tabular}


Kadar nitrogen awal sebelum pengomposan adalah 1,07\% dan setelah pengomposan selesai kadar $\mathrm{N}$ pada blotong yang menggunakan starter mikrobia X-kompos dan campuran vinasse $25 \%$ menjadi $4,16 \%$ dan kadar nitrogen pada blotong menggunakan starter mikrobia EM-4 menjadi 2,66\% pada penambahan vinasse $10 \%$. Mikroba menggunakan nitrogen untuk mengurai C (karbon) yang terdapat dalam bahan organik yang akan dikomposkan. Kebutuhan bakteri akan unsur $\mathrm{N}$ dapat dipenuhi dari sumber $\mathrm{N}$ yang terdapat dalam berbagai senyawa organik maupun $\mathrm{N}_{2}$ udara.

Adapun mekanisme penambatan nitrogen oleh bakteri yaitu: konversi $\mathrm{N}_{2}$ dari udara menjadi ammonia dibantu oleh enzim nitrogenase. Banyaknya $\mathrm{N}_{2}$ yang dikonversikan menjadi ammonia sangat tergantung pada kondisi fisik, kimia, dan biologi tanah. Ketersediaan sumber energi (C organik) di lingkungan rizosfir merupakan faktor utama yang menentukan banyaknya nitrogen yang dihasilkan. Rhizosfer merupakan tempat pertemuan antara tanah dengan akar tumbuhan. Jumlah mikrobia di daerah perakaran lebih banyak dibanding tanah yang tidak terdapat perakaran, karena di daerah perakaran terdapat nutrient-nutrien seperti asam amino dan vitamin yang disekresikan oleh jaringan akar [9].

Analisis Kadar $\mathrm{P}_{2} \mathrm{O}_{5}$ pada Kandungan N Optimum

Salah satu unsur hara pada pupuk yang harus diperhatikan adalah adanya $\mathrm{P}, \mathrm{P}$ di dalam pupuk terikat dalam senyawa $\mathrm{P}_{2} \mathrm{O}_{5}$. Berikut ini adalah kadar $\mathrm{P}_{2} \mathrm{O}_{5}$ yang dianalisis pada saat kadar $\mathrm{N}$ optimum. Yaitu pada saat penambahan vinasse $25 \%$ pada starter mikrobia X-kompos dan pada saat penambahan vinasse $10 \%$ pada starter EM-4.

Tabel 3. Hasil Analisis Kadar $\mathrm{P}_{2} \mathrm{O}_{5}$ Pada Saat Kandungan N Optimum

\begin{tabular}{cccc}
\hline \multirow{2}{*}{ No. } & \multirow{2}{*}{ Prosentase Vinasse } & \multicolumn{2}{c}{ Kadar $\mathbf{P}_{2} \mathbf{O}_{5}$} \\
\cline { 3 - 4 } & & EM- 4 & X-Kompos \\
\hline 1 & $25 \%$ & & 2,1158 \\
2 & $10 \%$ & 0,0825 & \\
\hline
\end{tabular}

Berikut ini adalah persyaratan teknis pupuk organik [11]

Tabel 4. Persyaratan Teknis Pupuk Organik

\begin{tabular}{ccccc}
\hline \multirow{2}{*}{ No } & Parameter & Satuan & \multicolumn{2}{c}{ Kandungan } \\
\cline { 4 - 5 } & & $\%$ & $>12$ & Padat \\
\hline 1 & C-organik & $\%$ & $12-25$ & 4,5 \\
2 & C/N ratio & $\%$ & maks 2 & \\
3 & Bahan ikutan (kerikil, & $\%$ & $4-12$ & \\
& beling, plasik) & $\%$ & $13-20$ & \\
4 & Kadar air granule & $\%$ & $4-8$ & $4-8$ \\
& Kadar air curah & & & $<5$ \\
5 & pH & $\%$ & $<5$ & $<5$ \\
\hline
\end{tabular}

Apabila kadar $\mathrm{P}_{2} \mathrm{O}_{5}$ dalam pupuk organik blotong hasil pengomposan dibandingkan dengan persyaratan di atas, maka masuk dalam kriteria yaitu kurang dari 5\%. Unsur P diperlukan dalam pertubuhan tanaman namun tidak boleh melebihi $5 \%$.

\section{Analisis Kadar $\mathrm{K}_{2} \mathrm{O}$ pada Kandungan N Optimum}

Untuk memperkaya kandungan hara dari pupuk yang dihasilkan dapat digunakan vinasse sebagai campuran blotong. Vinasse kaya akan unsur K sedangkan blotong kaya akan unsur N, P, dan Ca. Sehingga diharapkan pupuk organik yang dihasilkan akan mempunyai kandungan hara yang lebih lengkap daripada kandungan hara pupuk organik "Madros” yang sudah diproduksi di PG Madukismo.

Tabel 5. Hasil Analisis Kadar $\mathrm{K}_{2} \mathrm{O}$ Pada Saat Kandungan N Optimum

\begin{tabular}{cccc}
\hline \multirow{2}{*}{ No. } & \multirow{2}{*}{ Prosentase Vinasse } & \multicolumn{2}{c}{ Kadar K } \\
\cline { 3 - 4 } & & EM- 4 & X-Kompos \\
\hline 1 & $25 \%$ & & 1,26 \\
2 & $10 \%$ & 0,4672 & \\
\hline
\end{tabular}


Pada awal pengomposan blotong mempunyai kandungan $\mathrm{K}=0,6825 \%$ dan setelah akhir pengomposan kandungan $\mathrm{K}$ pada blotong dengan campuran vinasse $25 \%$ yang menggunakan starter mikrobia X-kompos bertambah menjadi $1,26 \%$ dan blotong dengan campuran vinasse $10 \%$ yang menggunakan starter mikrobia EM-4 berubah menjadi 0,4672\%. Bertambahnya kandungan K pada blotong karena disuplai dari kandungan $\mathrm{K}$ yang dimiliki oleh vinasse yang ditambahkan pada blotong. Berdasarkan Tabel 7 tentang persyaratan teknis pupuk organik, kadar $\mathrm{K}_{2} \mathrm{O}$ yang dipersyaratkan sudah sesuai yaitu $<5 \%$.

Analisis Rasio C/N pada Kandungan N Optimum

Analisis rasio $\mathrm{C} / \mathrm{N}$ setelah pengomposan dilakukan pada saat kadar $\mathrm{N}$ optimum.

Tabel 6. Hasil Analisis Rasio C/N Pada Saat Kandungan N Optimum

\begin{tabular}{cccc}
\hline \multirow{2}{*}{ No } & \multirow{2}{*}{ Kandungan Vinasse } & \multicolumn{2}{c}{ Rasio C/N } \\
\cline { 3 - 4 } & $25 \%$ & EM- 4 & X-Kompos \\
\hline 1 & $10 \%$ & 5,5 & 6,35 \\
2 & & & \\
\hline
\end{tabular}

Data dari analisis dapat kita lihat bahwa pada awal pengomposan rasio $\mathrm{C} / \mathrm{N}$ blotong sudah sangat rendah. $\mathrm{C} / \mathrm{N}$ rasio blotong awalnya 6,88 dan akhirnya setelah pengomposan blotong dengan campuran vinasse $25 \%$ yang menggunakan starter mikrobia X-kompos turun menjadi 6,35 dan blotong dengan campuran vinasse $10 \%$ yang menggunakan starter mikrobia EM-4 turun menjadi 5,5. Kompos yang matang secara biologis bersifat stabil dengan $\mathrm{C} / \mathrm{N}$ rasio yang relatif rendah antara 12-15 [10]. Berdasarkan data hasil penelitian diperoleh rasio $\mathrm{C} / \mathrm{N}$ sangat rendah, di bawah persyaratan teknis yang diperbolehkan. Blotong yang diperoleh dari PG Madukismo memiliki rasio $\mathrm{C} / \mathrm{N}$ yang relatif rendah.

\section{Perbandingan Hasil Analisis}

Berikut ini adalah perbandingan pupuk madros yang telah dikembangkan oleh PG Madukismo dan pupuk organik hasil dari penelitian ini dengan pupuk organik yang dipersyaratkan oleh Sudirja, 2007.

Tabel 7. Perbandingan Kandungan Pupuk Madros dengan Pupuk Blotong

\begin{tabular}{cccccc}
\hline No. & Parameter & Pupuk Madros A & Pupuk Madros B & Pupuk Blotong * & Sudirja, 2007 \\
\hline 1 & Kadar Air (\%) & 9,3 & 15,1 & 18,4 & $13-20$ \\
2 & $\mathrm{pH}$ & 9,75 & 9,1 & 7,45 & $4-8$ \\
3 & rasio C/N & 3,1 & 5,24 & 6,35 & $12-25$ \\
4 & $\mathrm{P}_{2} \mathrm{O}_{5}(\%)$ & 6,24 & 6,24 & 2,12 & $<5$ \\
5 & $\mathrm{~K}_{2} \mathrm{O}(\%)$ & 9,21 & 7,91 & 1,26 & $<5$ \\
\hline & & & *Pupuk organik hasil penelitian ini
\end{tabular}

Apabila kita mencermati tabel di atas, tampak bahwa pupuk organik yang diperoleh dari pengomposan blotong dengan penambahan vinasse menggunakan starter mikrobia, hampir memenuhi keseluruhan persyaratan pupuk yang ditetapkan oleh Sudirja, 2007. Rasio C/N yang masih belum sesuai. Hal ini dapat diatasi dengan menggunakan blotong yang memiliki rasio $\mathrm{C} / \mathrm{N}$ masih relatif tinggi.

Berdasarkan hasil penelitian yang diperoleh, penggunaan starter mikrobia X-kompos lebih prospektif dibandingkan menggunakan starter mikrobia EM-4 karena kompos yang dihasilkan oleh starter mikrobia Xkompos memiliki kandungan N, P, K yang jauh lebih tinggi daripada kompos yang dihasilkan oleh starter mikrobia EM-4. Sedangkan untuk penambahan vinasse, akan memberikan hasil optimum pada penambahan vinasse $25 \%$ dari berat blotong. Hal ini dapat dilihat dari kandungan N, P, K yang dihasilkan jauh lebih tinggi.

\section{Kesimpulan}

1. Blotong yang dihasilkan oleh PG Madukismo memiliki rasio $\mathrm{C} / \mathrm{N}$ yang rendah, hal ini menyebabkan blotong PG Madukismo dapat digunakan secara langsung sebagai pupuk organik tanpa dilakukan pengomposan, namun kekurangannya adalah kandungan N, P, K yang masih rendah.

2. Pengomposan blotong dengan penambahan vinasse dan menggunakan starter mikrobia dapat meningkatkan kandungan unsur N, P, K di dalam kompos yang dihasilkan.

3. Hasil optimum yang diperoleh adalah penggunaan starter mikrobia X-kompos dengan penambahan vinasse sebesar $25 \%$ berat blotong, akan menghasilkan pupuk kompos dengan kandungan $\mathrm{N}, \mathrm{P}, \mathrm{K}$ yang tinggi. 


\section{Daftar Lambang}

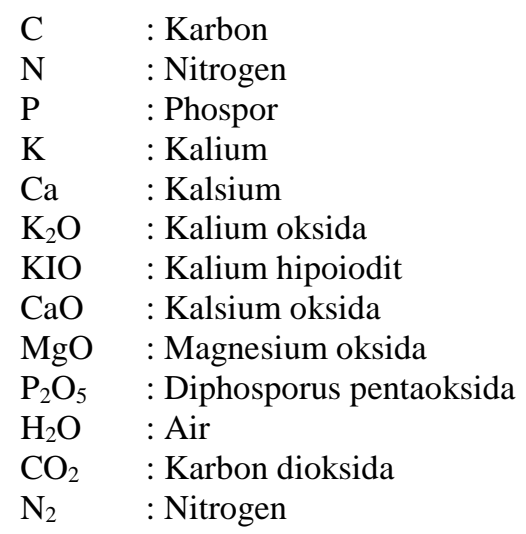

\section{Daftar Pustaka}

[1]. Santoso, Bambang Eddy. 2009. Limbah Pabrik Gula: Penanganan, Pencegahan Dan Pemanfaatannya Dalam Upaya Program Langit Biru Dan Bumi Hijau. Diakses dari http://fisika.brawijaya.ac.id/bssub//proceeding/PDF\%20FILES/BSS_357_1.pdf, pada 12 April 2014.

[2]. Gomez and Rodriguez, 2000. Effects of Vinasse on sugarcane (Saccharum officinarum) Productivity. Rev. Fac. Agron. Vol. 17, No. 4, pp. 318-326.

[3]. Anonim, 2008. Kompos. Diakses dari: http://id.wikipedia.org/wiki/Kompos, pada 21 April 2014.

[4]. Isroi, 2009. Pupuk Organik Granul. http://isroi.worpress.com, 9 April 2009

[5]. Ariko dan Fitriani, M. 2009. Pemanfaatan Limbah Blotong Pabrik Gula Cinta Manis Menjadi Pupuk Kompos Dengan Menggunakan Aktivator Effective Microorganisme-4. Diakses dari: http://digilib.polisriwijaya.ac.id/gdl.php?mod=browse\&op=read\&id=ssptpolsri-gdl-meilindafi-1763, 23 April 2014.

[6]. Anonim, 2009. Potensi Limbah Pabrik Gula Sebagai Sumber bahan Organik. Diakses dari http://disbunjatim.co.cc/bahan_organik/potensi_limbah_sbg_bo.html, pada 21 April 2014.

[7]. Ariko dan Fitriani, M. 2009. Pemanfaatan Limbah Blotong Pabrik Gula Cinta Manis Menjadi Pupuk Kompos Dengan Menggunakan Aktivator Effective Microorganisme-4. Diakses dari: http://digilib.polisriwijaya.ac.id/gdl.php?mod=browse\&op=read\&id=ssptpolsri-gdl-meilindafi-1763, 23 April 2014.

[8]. Dallzell, H. W. AJ. Riddlestone, K.R. Gray and K Thurairajan. 1987. Soil management: compost production and use in tropical and subtropical environments. FAO. Rome. Soil Bull 56:175-177

[9]. Anonim, 2011. Rhizosfer. Diakses dari https://kamriantiramli.wordpress.com, pada 14 April 2015.

[10]. Sudirja, 2007. Modul Pembuatan Kompos: Standar Mutu Pupuk Organik dan Pembenah Tanah. Departemen Tenaga Kerja dan Transmigrasi R.I. Lembang. 